\title{
Do Conceptions of Learning Predict Language Learning Strategies? Evidence from Indonesian EFL Learners
}

\section{DAIRABI KAMIL*}

\begin{abstract}
Research has shown that information on students' conceptions of learning (COL) and their language learning strategies (LLS) are beneficial for understanding certain recurring phenomena of foreign language learning and outcomes. However, these two constructs have been separately studied from each other. This study sought to fill this void by investigating the relationship between the constructs and the extent to which COL predicts LLS. Data were collected by administering the Conceptions of Learning Inventory (COLI) and Strategy Inventory for Language Learning (SILL) to 210 pre-service EFL teachers at an English department of a state higher education institution in Indonesia. Data were analyzed using the nonparametric Spearma's-Rho test and Regression Tree (RT) analysis technique. The results show statistically significant positive correlations between the two constructs. Further analyses show that COL, to some extent, predicted LLS.
\end{abstract}

\section{Keywords}

Conceptions of learning, EFL, language learning strategies, regression tree

* Associate Professor, Institut Agama Islam Kerinci, Jambi, Indonesia; drbkml@gmail.com 


\section{IRJE | Indonesian Research Journal in Education | | Vol. 5 | No. 2| December|Year 2021|}

\section{Introduction}

Studies on Conceptions of Learning (COL) in different contexts repeatedly showed significant effects the construct had on teaching and learning processes. Studies on teachers, for example, showed that COL influences their teaching behaviors (Martin, Pozo, Mateos, Martin, \& Echeveria, 2014) in terms of teacher centeredness and orientation to professional practice (Jacobs, Wilschut, van der Vleuten, Scheele, Croiset, \& Kusurkar, 2020), teacher efficacy beliefs (Bahcivan \& Kapucu, 2014), technology acceptance (Teo \& Zhou, 2016) and teachers' choices of teaching strategies (Donche \& van Petegem, 2016). Studies on students' COL showed that the construct contributed to, among others, students' academic achievements (Peterson, Brown, \& Irving, 2010; Alamdarloo, Moradi , \& Dehshiri, 2012; Lonka, Ketonen \& Vermunt, 2021;), the quality of learning outcomes (Chaleta, Gracio \& Ramalho, 2012); learning motivation (Negovan, Sterian, \& Colesniuc, 2015), and study habits (Heidarzadeh, Tirgari, Azizzadeh, Forouzi, Shafiean, Vadiati, \& Saeid, 2020).

Furthermore, the relationships between students' COL and their learning strategies in different levels of education and subjects have also been identified. COL was found to be related to, among others; Taiwanesse high school students' strategies in learning biology (Shen, Li, \& Lee, 2018; Sadi, 2017), Italian upper secondary school students' learning strategies (Vettori, Vezzani, Bigozzi, \& Pinto, 2020), Chinese secondary school students' strategies in learning science (Li, Zheng, Liang, Zhang, \& Tsai, 2018), Iranian university students' strategies in virtual and real space learning (Abbasi, Pourshahriar, \& Fathabadi, 2017). All these studies suggest strong associations between COL and learning strategies.

Similarly, studies on Language Learning Strategies (LLS) also suggested a strong association between the construct with language learners' achievements and other related variables. LLS, for example, was found to be associated with EFL learners' proficiency (Magno, 2010; Gerami \& Baighlou, 2011; Tragant \& Victory, 2012; Irgatoglu, 2021), self-efficacy (Montaño-González, \& Cancino, 2020), extraversion and introversion (Taheri, Sadighi, Bagheri, \& Bavali, 2020), language learning motivation (Ranjan \& Philominraj, 2020), academic self-concept (Biyikl, 2021), personality traits (Obralic \& Mulalic, 2017). In addition, researchers also found that EFL learners' LLS specifically predicted their mastery of the four language skills, i.e. listening (Goh \& Vandergrift; 2021; Caskun, 2010), reading (Puspita, 2016; Ghafournia, 2014; Nasab \& Motlagh, 2015, Nazurty et al., 2019), speaking (Septikawati, Kristina, Nurkamto, 2019; Cabaysa \& Baetiong, 2010) and writing (Pitenoee, Modaberi, \& Ardestani 2017; Sabria, 2016; Chand, 2014).

However, although research findings suggested the significant effects of COL and LLS on various aspects of language learning and the associations between students' COL and learning strategies in general, to date, research that explores the relationship between EFL learners' COL and their LLS is still absent. In light of the absence, the current study seeks to fill the void by exploring the issue. The results of the study are important for a better understanding of language learning phenomena in general, and of EFL learning in particular. Specifically, the this study seeks to answer the following research questions:(1) Do 


\section{IRJE | Indonesian Research Journal in Education | | Vol. 5 | No. 2| December|Year 2021|}

Indonesian EFL learners' conceptions of learning (COL) correlate with their language learning strategies (LLS)?; and (2) Do Indonesian EFL learners' conceptions of learning (COL) predict their language learning strategies (LLS)?

\section{Literature Review}

The current study sought to explore the causal relationship between two constructs, i.e. conceptions of learning and language learning strategies. In accordance with this focus, this section discusses theories that underpin the constructs explored in this study.

\section{Conceptions of learning}

Research of conceptions of learning was pioneered by Saljo (1979) who studied the learning experience and techniques of Swedish students'. The participants of the study were asked to define what learning meant to them. The findings showed that the participants perceived learning in five different concepts, i.e. (1) an increase in knowledge; (2) memorizing; (3) an acquisition of facts or principles, which can be retained and used in practice; (4) an abstraction of meaning; and (5) an interpretive process aimed at understanding reality. The study further distinguished the conceptions into two categories, i.e. surface- level and deep-level processing. The concepts of learning as memorizing and as an acquisition of facts or principles, which can be retained and used in practice, were categorized as surface-level processing as they perceive new knowledge as a complete externality to be passively incorporated into one's knowledge repertoires. While, the concepts of learning as an abstraction of meaning and as an interpretive process aimed at understanding reality were categorized as deep-level processing as they perceive new knowledge needs to be actively related to one's existing knowledge and previous experiences in order to understand its meaning (Saljo,1979).

Later on, following Saljo's (1979) suggestions that “... learning does not exist as a general phenomenon. To learn is to act within man-made institutions and to adapt to the particular definitions of learning that are valid in the educational environment in which one finds oneself" (p. 106) and that "the meaning of the concept of learning is highly ambiguous and not susceptible to any analytically satisfactory definition" (p. 104), researchers had studied conceptions of learning of students from different cultural background. Research by Marton, Dall'Alba, and Tse (1993), for example, found both identical and different understanding of learning among Chinese teacher educators when compared to Western concepts of learning. The study showed that, contrary the Western concepts that distinguish memorization from understanding; the Chinese teacher educators saw that memorization was a mutual part of the process of understanding. Different concepts were also reported from research on Nepalese students (Watkins \& Regmi, 1992; Watkins, Regmi, \& Astilla, 1991). The research showed that the students did not associate learning with memorization.

To further explore research findings on cross-cultural conceptions of learning, Purdie, Hattie, and Douglas (1996), conducted a qualitative research on conceptions of learning of Japanese and Australian students. The study identified nine conceptions of learning. Learning was perceived as: (1) increasing one's knowledge; (2) memorizing and 


\section{IRJE | Indonesian Research Journal in Education | | Vol. 5 | No. 2| December|Year 2021|}

reproducing information; (3) using information as a means to an end; (4) understanding; (5) seeing something in a different way; (6) personal fulfillment; (7) a duty; (8) a process not bound by time or context; and (9) developing social competence. Based these findings Purdie and Hattie (2002) constructed a 112 item inventory that measure the nine conceptions of learning. The first administration of the inventory resulted in 45 items. While the second administration left 32 items that measure six conceptions of learning: (1) gaining information; (2) remembering, using, and understanding information; (3) duty; (4) personal change; (5) process not bound by time or place, and (5) the development of social competence.

In order to check the validity, reliability, and the cross-cultural robustness of the inventory, Purdie and Hattie (2002) administered the inventory to 1694 students from five different ethnic backgrounds, i.e. Non-Aboriginal Australian, Aboriginal Australian, Malaysian, Caucasian American, and African American. Assessment of fit statistics showed that inventory, which is called Conceptions of Learning Inventory (COLI), could measure the construct well across the different cultural groups of student, with an exception for the Australian Aboriginal group due to high interscale correlation. In addition, the researchers reported that across groups internal consistency reliability indexes ranged from .45 to .92, with a mean of .74 and a median of .76 (Purdie \& Hattie, 2002). Ever since, a great number studies that used COLI across different contexts and students' cultural backgrounds (e.g., Mulyani, Suherdi, \& Sundayana, 2020; Pinto, Bigozzi, Vettori, \& Vezzani, 2018; Chaleta, 2018; Chan, 2011; Peterson, Brown, \& Irving; 2010) reported satisfactory psychometric properties of the inventory. The present used the Conceptions of Learning Inventory (COLI).

\section{Language learning strategies}

Theories and research on LLS started to develop in the early 1970s. Two of the earliest definitions of LLS are "the techniques or devices which a learner may use to acquire knowledge" (Rubin, 1975, p 43) and "...optional means for exploiting available information to improve competence in a second language" (Bialystok, 1978, p. 71). Later, Oxford (1990) defines language learning strategy as "Specific actions taken by the learner to make learning easier, faster, more enjoyable, more self-directed, more effective, and more transferable to new situations" (p.8). The present study refers to the last definition and used an inventory developed based on it. Scholars have proposed different classifications of LLS. Bialystok (1978) suggested a four- category classification based on the types of practices and information processing in language learning: (1) formal practicing, i.e. learning a language by practicing language rules; (2) functional practicing, i.e. learning a language by using it for communication purposes; (3) monitoring strategies, i.e. learning a language through modification, examination, and correction of linguistic outputs; and (4) inferencing Strategies, i.e. learning a language by guessing of unknown inputs or forms. Fillmore (1979) proposed two categories of LLS, i.e., cognitive strategies and social strategies. The former assumes that language learners actively identify patterns of the target language, while in the latter language learning is pursued through interacting with people. Rubin (1981) suggested 


\section{IRJE | Indonesian Research Journal in Education | | Vol. 5 | No. 2| December|Year 2021|}

an LLS classification consisting of (1) Direct Strategies which is characterized by clarifying, memorizing, guessing, inductive inferencing, and deductive reasoning, and (2) Indirect Strategies which is characterized by use of linguistic performance competencies.

The most widely referred to classification of LLS has been Oxford's (1990), which is also the classification used in the present study. The classification draws on six strategies, i.e.(1) Memory Strategies which include creating mental linkages, applying images and sounds, reviewing, and taking actions or responding to the target language; (2) Cognitive Strategies which include practicing, receiving and sending, analyzing and reasoning, and creating structure for target language inputs and outputs; (3) Compensation Strategies which include the use of intelligent guessing and finding ways to overcome barriers in speaking and writing ; (4) Metacognitive Strategies which deals with self-coordinating of learning process such as focusing, arranging, planning and evaluating learning; (5) Affective Strategies which focus on managing psychological issues such as anxiety, motivation, and emotion; and (6) Social Strategies which focus on collaborative learning. Furthermore, Oxford (1990) classifies the six strategies into two types, i.e. Direct Strategies and Indirect Strategies. Direct Strategies are subconscious, inherently learned and related directly to the target language. This type of strategy includes Memory Strategies, Cognitive Strategies, and Compensatory Strategies. Indirect Strategies operate under the learner's conscious control or acts and focus on organizing the overall language learning process. These include Metacognitive Strategy, Affective Strategies, and Social Strategies.

Based on her classification of LLS, Oxford (1990) constructed an inventory for measuring language learning strategies called Strategy Inventory for Language Learning (SILL). SILL comes in two versions; Version 5.1, which was designed for native English speakers learning, and Version 7.0 (henceforth, referred to as SILL in this report) which was designed for non-English speakers who are learning English. SILL consists of 50 items purported to measure the 6 categories of LLS proposed by Oxford (1990). Assessments of the psychometric properties the inventory in different EFL and ESL contexts (e.g., Nykos \& Oxford, 1993; Oxford \& Burry-Stock, 1995; Hsiao \& Oxford, 2002) produced a very high reliability $(\alpha=0.9-0.94)$.

\section{Methodology}

\section{Research design, site, and participants}

This study is quantitative and ex post facto in nature. It draws on the correlational strategy and seeks to: (1) determine whether or not there is a significant correlation among the participants' COL and LLS, and (2) determine the extent to which their COL as the independent variable or predictor predicts their LLS as the dependent variable. This study involved 210 pre-service EFL teachers who were, at the time of data collection, in their $1^{\text {st }}$, $3^{\text {td }}, 5^{\text {th }}$, and $7^{\text {th }}$ semester at an English department of a state higher education institution in Indonesia. Students of higher semesters were not involved in the study as they were mostly unavailable on campus as most of them were in their thesis writing stage of their study completion. The demographic information of the participants is summarized in the following table: 


\section{IRJE | Indonesian Research Journal in Education | | Vol. 5 | No. 2 | December | Year 2021|}

Table 1. Research participants' demography

\begin{tabular}{llll}
\hline & & $\mathrm{n}$ & $\%$ \\
\hline \multirow{3}{*}{ Semester } & I & 63 & 30 \\
& III & 56 & 26 \\
& V & 50 & 24 \\
& VII & 41 & 20 \\
Gender & Total & 210 & 100 \\
& Male & 54 & 26 \\
& Female & 156 & 74 \\
& Total & 210 & 100 \\
\hline
\end{tabular}

\section{Data collection and analysis}

Data were collected by administering the Indonesian version of Conceptions of Learning Inventory (Purdie \& Hatie, 2002) and Strategy Inventory for Language Learning (Oxford, 1990) to the 210 participants through on-line survey forms. The COLI consists of 32 items that measure 6 conceptions of the construct (Table 2). For example, item 1, one of the items that measures conception of learning as gaining information, reads "Learning is when I am taught something that I didn't know about before". The SILL consists of 50 items measuring 6 strategies (Table 2). The word "English" was added to the items for the focus of the study was on the learners' strategies in learning English. As an example, item 1, one of the items that measures memory strategies reads "I think of relationships between what I already know and new things I learn in English". In addition, considering the fact that the study was conducted in an EFL context where participants' interactions with native speakers of English hardly happen, two items of the SILL, i.e. item 46 and item 48, that contain statements on asking for native speakers' correction and assistance in English learning were considered irrelevant and, therefore, removed from the inventory. This left 48 items in the administered inventory for data collection.

Both inventories were assigned a five-category response for each of their items. For the Conceptions of Learning Inventory the responses were coded as $1=$ Strongly Disagree, $2=$ Disagree, $3=$ Neutral, $4=$ Agree, and $5=$ Strongly Agree. Responses for the Strategy Inventory for Language Learning were coded as $1=$ Never, $2=$ Seldom, 3 = Sometimes, $4=$ Often, and $5=$ Always. The higher or the lower a respondent's agreement with an item was respectively interpreted to reflect the more or the lesser his or her association with the conception of learning or use of language learning strategy being measured by the item.

To ensure the accuracy of the Indonesian translation of the inventories, back-to-back translation procedures were conducted and the results were evaluated by two competent English lecturers of English. Both evaluators agreed on the accuracy and appropriateness of the translation to be used in the present study. 


\section{IRJE | Indonesian Research Journal in Education | | Vol. 5 | No. 2| December|Year 2021|}

Table 2. Dimensions and items of COLI and SILL

\begin{tabular}{ll}
\hline Predictors & \\
\hline Conceptions of Learning (COL) & items \\
\hline Learning as gaining information (LCInfo) & $1,7,13,19,23$ \\
Learning as remembering, using, and understanding & $2,8,14,20,25,26,28,30,32$ \\
information (LCRUU) & \\
Learning as a duty (LCDuty) & $3,9,15$ \\
Learning as personal change (LCPers) & $4,10,16,21,25,27,29,31$ \\
Learning as a process not bound by time or place (LCProc) & $5,11,17$ \\
6. Learning as the development of social competence & $6,12,18,22$ \\
(LCSoc) & \\
\hline Dependent Variable & Items \\
\hline Language Learning Strategies (LLS) & $1,2,3,4,5,6,7,8,9$ \\
\hline 1.Memory (LLSMem) & $10,11,12,13,14,15,16,17,18,19,20,21,22,23$ \\
2.Cognitive (LLSCog) & $24,25,26,27,28,29$ \\
3.Compensatory (LLSComp) & $30,31,32,33,34,35,36,37,38$ \\
4.Metacognitive (LLSMeta) & $39,40,41,42,43,44$ \\
5.Affective (LLSAfc) & $45,47,49,50$ \\
6.Social (LLSSoc) & \\
\hline
\end{tabular}

Data analyses were conducted in four phases. First, the data obtained from the administration of the two inventories were analyzed for validity and reliability using Rasch analysis on Winsteps Rasch Analysis computer software (Linacre, 2006). Second, as the data resulting from the two instruments were non-linear and ordinal in nature, they were converted into interval ones using Method of Interval (MSI) and analyzed for descriptive statistics. At this point of analysis, assessments of data properties in terms of normality and homogeneity were conducted and a decision on the choice of using either parametric or non-parametric data analysis techniques for the next analyses was made. Third, in order to answer the first research question, the data were analyzed to determine the correlation between COL and LLS. The analysis was conducted using Spearman's Rho non-parametric technique as the results of analysis in phase two showed that the data were not normally distributed. Fourth, to determine the extent to which COL predicts LLS which is the second research question, Regression Tree (RT) analysis technique was used to suit the non-normally distributed data sets.

$\mathrm{RT}$ is a non-parametric regression technique that models causal interactions between a dependent variable and predictor variables. RT is built based on recursive partitioning of the data space into smaller portions that identify the most significant predictors of a dependent variable. The divisions proceed with information provided by each predictor on the cut-off score for the maximum partitioning of the data. RT analysis outputs are presented in a hierarchical binary tree consisting of nodes and edges. The edges that connect the nodes indicate the relative level of the nodes within the tree's hierarchical structure Each node presents the estimates of mean (M), standard deviation (SD), and number of observations associated with it (Blanch \& Aluja, 2013). The second, the third, and the fourth phase of data analyses were conducted using IBM SPSS computer statistical analysis software Version 26. 


\section{IRJE | Indonesian Research Journal in Education | | Vol. 5 | No. 2 | December | Year 2021|}

\section{Findings}

\section{Validity and reliability}

To assess the validity of the instruments, examination of Item Polarity and Item Fit Statistics (Bond \& Fox, 2013) which respectively indicated by Point Measure Correlation (PTMEACORR) and Infit Mean Square (IMNSQ) values of Winsteps Rasch analysis computer software outputs was conducted. The results showed that all the items of the two instruments had a positive value ranging from .15 to .55 for the COLI and .15 to .64 for the SILL. While for IMNSQ, with an acceptable fit statistics values between 0,5 to 1,5 (Linacre, 2006), two items of the COLI, i.e. item 3 and item 15 and two items of the SILL, i.e. item 26 and item 43 were found to have a value outside the range. However, as up to $5 \%$ of items may misfit by chance (Smith, 1991), the misfitting items were retained for the data analyses and the instruments were considered valid. As for reliability, the reliability indices of item difficulty estimate of .94 for the COLI and .98 for the SILL are considered very high. This indicates a high probability that similar order of item difficulty would be produced if the set of questionnaires is administered to other comparable samples.

\section{Descriptive statistics}

Assessment of descriptive statistics (Table.3) show that the means for LC range from 3.95 to $4.37, \mathrm{SD}=.478$ to .568 . While the means for LLS range from 2.88 to $3.37, \mathrm{SD}=$ .499 to .647. The skewness values for LC indicate that the data were not normally distributed, $p=<.001$ while the skewness values for LLS indicate that the data were normally distributed, $p=>.05$. As such, non-parametric techniques were used for the next data analyses.

Table 3. Summary of predictors and dependent variables statistics

\begin{tabular}{llllllll}
\hline COL & Mean & Mean Rank & SE & SD & Skewness & SE & $\mathrm{p}$ \\
\hline LCInfo & 4.12 & 4 & 0.0339 & 0.492 & -0.8807 & 0.168 & $<.001$ \\
LCRUU & 4.19 & 2 & 0.0330 & 0.478 & -0.6998 & 0.168 & $<.001$ \\
LCPers & 4.37 & 1 & 0.0334 & 0.484 & -0.4940 & 0.168 & $<.001$ \\
LCDuty & 3.95 & 6 & 0.0389 & 0.563 & -0.2109 & 0.168 & $<.001$ \\
LCProc & 3.98 & 5 & 0.0389 & 0.563 & -0.7498 & 0.168 & $<.001$ \\
LCSoc & 4.17 & 3 & 0.0392 & 0.568 & -0.7066 & 0.168 & $<.001$ \\
LLSMem & 3.37 & 2 & 0.0344 & 0.499 & -0.2251 & 0.168 & 0.262 \\
LLSCog & 3.15 & 3 & 0.0366 & 0.531 & -0.0385 & 0.168 & 0.701 \\
LLSComp & 3.02 & 5 & 0.0389 & 0.564 & -0.1467 & 0.168 & 0.452 \\
LLSMeta & 3.71 & 1 & 0.0431 & 0.625 & -0.2106 & 0.168 & 0.348 \\
LLSAfc & 2.88 & 6 & 0.0376 & 0.545 & 0.1443 & 0.168 & 0.198 \\
LLSSoci & 3.06 & 4 & 0.0446 & 0.647 & -0.0193 & 0.168 & 0.080 \\
\hline
\end{tabular}


Examination of the means for LC and LLS showed that the most held LC was LCPers, $\mathrm{M}=4,37, \mathrm{SE}=.0334, \mathrm{SD}=.484$, and the least held LC was LCDuty, M=3.95, $\mathrm{SE}=.0389, \mathrm{SD}=.563$. The most used LLS was LLSMeta, $\mathrm{M}=3.71$, and the least used LLS was LLSAfc, $\mathrm{M}=2.88, \mathrm{SE}=.0376, \mathrm{SD}=.545$. The complete order of the participants' LC and LSS are presented in the mean rank column of Table 3. However, Kruskal-Wallis Test showed that there was no significant difference among the means of both LC and LSS, $p=>.05$.

\section{Correlations among the participants' conceptions of learning (COL) and their language learning strategies (LLS)}

As examination of the two data sets showed that they were not normally distributed, the non-parametric technique of Spearman's Rho was used to explore the correlations among the participants' COL and LLS. The omnibus test showed a positive correlation between the two constructs, $\mathrm{r}_{\mathrm{s}}(208)=.20, p=.004$. Furthermore, computations of correlations among individual conceptions of learning and language learning strategies of the (Table 4) also yielded significant positive correlations between: (1) LCInfo and LLSComp, LLSMeta, and LLSSoc; (2) LCRUU and LLSCog ,LLSComp, and LLSSoc; (3) LCPers and LLSCog,LLSComp, LLSMeta, and LLSSoc (4) LCProc and LLSMem, LLSCog, and LLSMeta; and (5)LCSoc and LLSMem. However, no COL was found to correlate with LLSAfc and no LLS was found to correlate with LCDuty.

Table 4. Correlations among COL and LLS

\begin{tabular}{|c|c|c|c|c|c|c|c|}
\hline & & LCInfo & LCRUU & LCPers & LCDuty & LCProc & LCSoc \\
\hline \multirow[t]{2}{*}{ LLSMem } & $\mathrm{r}_{\mathrm{s}}$ & 0.084 & 0.127 & 0.091 & -0.073 & 0.238 & 0.161 \\
\hline & $\mathrm{p}$ & 0.225 & 0.067 & 0.188 & 0.289 & $<.001$ & 0.020 \\
\hline \multirow[t]{2}{*}{ LLSCog } & $r_{s}$ & 0.083 & 0.148 & 0.181 & -0.104 & 0.237 & 0.105 \\
\hline & $\mathrm{p}$ & 0.230 & 0.032 & 0.008 & 0.133 & $<.001$ & 0.129 \\
\hline \multirow[t]{2}{*}{ LLSComp } & $r_{s}$ & 0.176 & 0.214 & 0.146 & -0.023 & 0.035 & 0.049 \\
\hline & $\mathrm{p}$ & 0.011 & 0.002 & 0.034 & 0.739 & 0.613 & 0.478 \\
\hline \multirow[t]{2}{*}{ LLSMeta } & $r_{s}$ & 0.180 & 0.121 & 0.210 & -0.071 & 0.172 & 0.070 \\
\hline & $\mathrm{p}$ & 0.009 & 0.079 & 0.002 & 0.306 & 0.013 & 0.312 \\
\hline \multirow[t]{2}{*}{ LLSAfc } & $r_{s}$ & 0.130 & 0.102 & 0.064 & 0.133 & 0.092 & 0.076 \\
\hline & $\mathrm{p}$ & 0.060 & 0.142 & 0.357 & 0.055 & 0.186 & 0.275 \\
\hline \multirow[t]{2}{*}{ LLSSoc } & $\mathrm{r}_{\mathrm{s}}$ & 0.180 & 0.204 & 0.155 & -0.097 & 0.094 & 0.086 \\
\hline & $\mathrm{p}$ & 0.009 & 0.003 & 0.024 & 0.162 & 0.175 & 0.217 \\
\hline
\end{tabular}




\section{IRJE | Indonesian Research Journal in Education | | Vol. 5 | No. 2| December|Year 2021|}

\section{Conceptions of learning (COL) predictors of language learning strategies (LLS)}

To define whether or not and which COL predicts LLS, RTs were conducted. A full model that comprised all the six predictors (COL) was against each of the LLS, and resulted in the identifications of the most important predictors (COL) of LLS shown in Figure 1. The figure shows that RT analyses estimated 4 most important predictors for 4 LLS. However, No significant predictor was estimated for LLSMeta and LLSAfc. Specifically, the figure shows that based on $\mathrm{N}=210$ observations: (1) conceptpion of learning as a process not bound by time or place (LCProc) was the best predictor of memory learning strategies (LLSMem) $\mathrm{M}=3.372, \mathrm{SD}=0499, \mathrm{~F}=15.447, \mathrm{df2}=208, p=.001$. If LCProc values were $<=$ the cut-off score of 3.653, then the estimated M of LLSMem was 3.178, SD=0.508, $\mathrm{n}=66$ (31.4\%). If LCProc values were greater than 3.653, the estimated M of LLSMem was 3.460, $\mathrm{SD}=0.471, \mathrm{n}=144(68.6 \%)$; (2) conception of learning as a process not bound by time or place (LCProc) was best predictor of cognitve learning strategies (LLSCog), M=3.149, $\mathrm{SD}=0.531, \mathrm{~F}=14,649, \mathrm{df} 2=208, p=.002$. If LCProc values were $<=$ the cut-off score of 3.653 , then the estimated M of LLSCog was 2.948, $\mathrm{SD}=0.510, \mathrm{n}=66(31.4 \%)$. If LCProc values were greater than 3.653, the estimated M of LLSCog was 3.241, SD=0.516, $\mathrm{n}=144$ (68.6\%); (3) conception of learning as remembering, using, and understanding information (LCRUU) was the best predictor of Compensation learning strategy (LLSComp), $M=3.023$, $\mathrm{SD}=0.564, \mathrm{~F}=7.962, \mathrm{df} 2=208, p=.047$. If LCRUU values were $<=$ the cut-off score of 4.372 , then the estimated M of LLSComp was $2.395, \mathrm{SD}=0.563, \mathrm{n}=126(60 \%)$. If LCRUU values were greater than 4.372 , the estimated M of LLSCog was 3.155, SD=0.542, $\mathrm{n}=84$ (40\%). and (4) conception of learning as remembering, using, and understanding information (LCRUU) was the best predictor of social learning strategies (LLSSoc), $\mathrm{M}=3.059, \mathrm{SD}=0.647, \mathrm{~F}=7.983, \mathrm{df} 2=208, p=.047$. If LCRUU values were $<=$ the cut-off score of 4.150 , then the estimated M of LLSSoc was $2.907, \mathrm{SD}=0.606, \mathrm{n}=84(40 \%)$. If LCRUU values were greater than 4.150 , the estimated M of LLSSoc was 3.160, SD=0.655, $\mathrm{n}=126(60 \%)$.

Figure 1. Tree-plots for the most important predictors of LLS
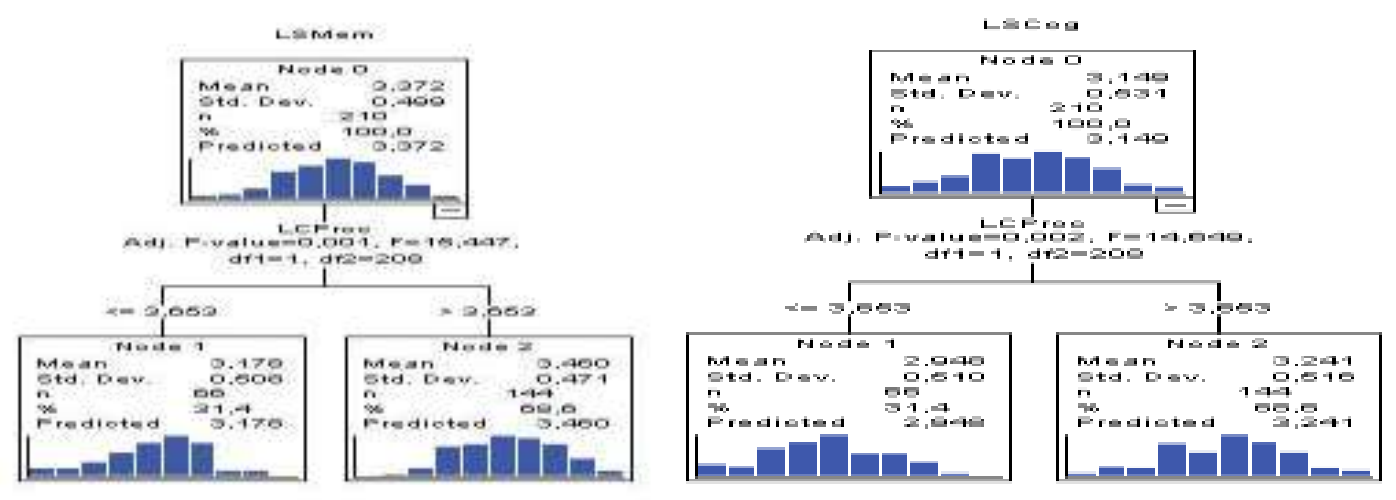


\section{IRJE | Indonesian Research Journal in Education | | Vol. 5 | No. 2 | December | Year 2021|}

Figure 1. Continued...
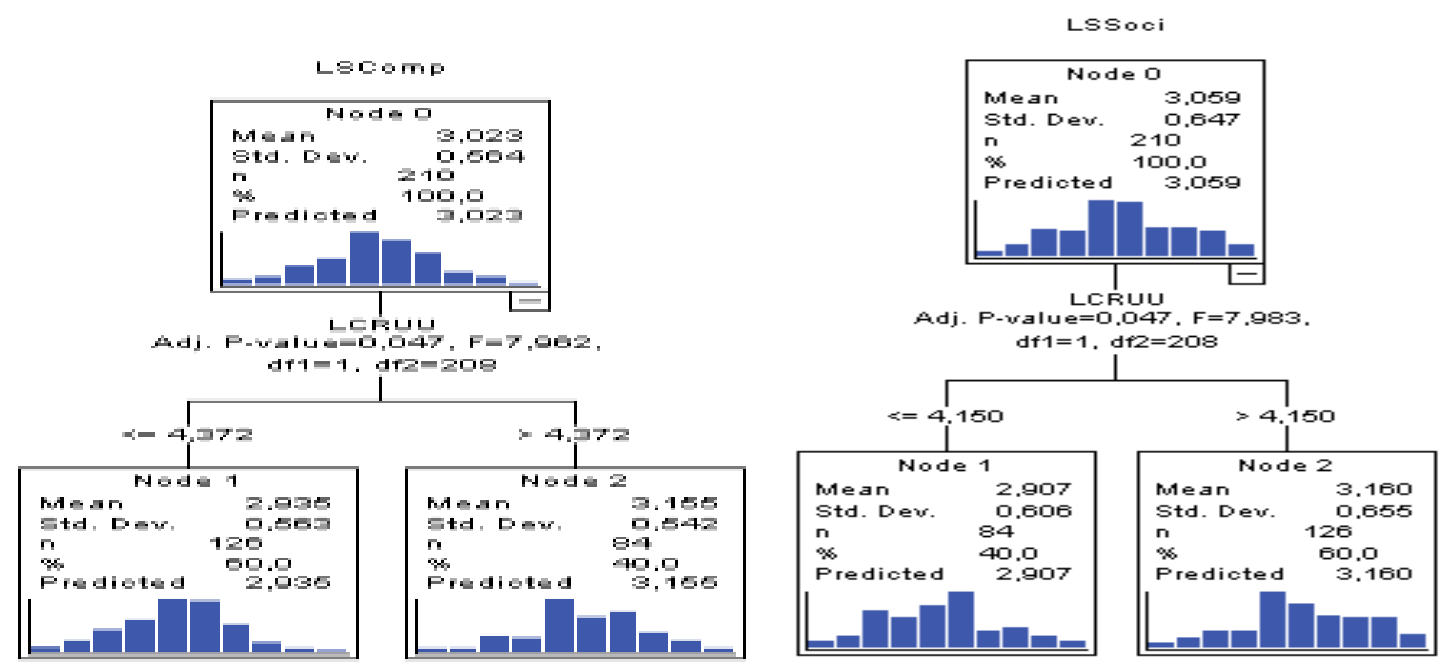

\section{Discussion}

The study revealed that, despite the statistically insignificant mean differences, the respondents' most dominant conception of learning was learning as personal change. When confronted with Surface and Deep Learning theory, it can be readily recognized that the learning conception falls into the deep learning category where learners aim for meanings, problem solving, connecting schemata to new knowledge, and relating theory to practice (Walker, 2012). In fact, the order of dominance of the conceptions of learning identified in the present study reflects a partition that divides them in two halves of deep and surface learning respectively. The first three conceptions in the order, i.e. Learning as personal change (LCPers), learning as the development of social competence (LCSoc), and learning as a process not bound by time or place (LCProc) are all related to deep learning. While the second three conceptions of learning in the order, i.e. learning as gaining information (LCInfo), learning as duty (LCDuty), and learning as remembering, using, and understanding information (LCRUU), are all related to surface learning that focuses on obtaining and reproducing information, task accomplishment, and memorizing facts and procedures (Walker, 2012). These findings suggest that most of the respondents conceptualized learning in the deep learning realm. The findings are also in line with Gan, Liu, and Yang's (2017) study on Chinese pre-service EFL teachers, and Santosa's (2017) study on Indonesian pre-service EFL teachers in the context of the implementation of flipped learning, that found the dominance of deep learning approach among their respondents. A different finding, however, was recorded by Hulreski, Syatriana, and Ardiana (2020) in their study on Indonesian pre-service EFL teachers' learning approach toward vocabulary acquisition where they found alignment to surface learning. This is understandable as vocabulary acquisition requires rote learning. To this end, a preliminary 


\section{IRJE | Indonesian Research Journal in Education | | Vol. 5 | No. 2| December|Year 2021|}

theory could be proposed here that when dealing with the overall aims of learning, pre-service EFL teachers perceive their conceptions of learning within a deep learning perspective. While, when confronted with specific tasks language learning, such as vocabulary acquisition, they perceive their conceptions of learning within a surface learning perspective.

The descriptive statistics shows that the respondents' most dominant language learning strategies were metacognitive strategies (LLSMem), and the least used strategies were social strategy (LLSSoc). These findings are similar to those of Kamil, Hartono, and Vintoni (2017) who also studied the issue of Indonesian pre-service EFL teachers. However, although also finding the metacognitive strategies as the most used strategies, studies by Lestari and Wahyudin (2020), Tanjung (2018), and Rianto (2020) reported that their respondents' least used strategy was the affective strategies, memory strategies, and compensatory strategy respectively. The similarity of the finding of the present and other studies in terms of the most used language learning strategy seems to suggest a common pattern among Indonesian pre-service EFL teachers.

The present study found a positive relationship between the conceptions of learning and the language learning strategies. Although, studies in other fields such as medicine education (Chiu, Liang, Hsu, Chu, Lin, Chen, \& Tsai, 2019), education degree program (Chan, 2007), biology education (Sadi, 2017), high school students (Shen, Li, \& Lee, 2018) identified such a relationship with a varying magnitudes, as far as the literature is concerned, there has not been research that studied the relationship among conceptions of learning and language learning strategies. Therefore, the finding of the present study regarding the issue is novice in nature.

Overall, the results of RT analysis show that, to some extent, COL predicted LLS. Specifically, the conception of learning as a process not bound by time or place (LCProc) predicted memory strategies (LLSMem) and cognitive strategies (LLCog). The conception of learning as remembering, using, and understanding information (LCRUU) predicted cognitive learning strategies (LLSCog) and compensation learning strategies (LLSComp). These findings convergently concurred with the descriptive statistics that showed the two COLs were the most held conceptions by the participants of the study, and with the results of the nonparametric test of correlation that showed the associations among the two COLs with the four LLS were the strongest, $\mathrm{p}=<.004$. However, regarding the fact that none of the conceptions of learning predicted metacognitive strategies (LLSIMeta), which was the most used strategies, and affective strategies (LLSAfc), which was the least used strategies, the explanation is beyond the scope of the present study.

\section{Conclusion and Recommendations/Implications}

This study identified significant positive association among EFL learners' conceptions of learning and their English language learning strategies. The specific conceptions of learning that predicted particular English language learning strategies were also identified. The findings may add some new perspectives to the so far uncharted area between the constructs of conceptions of learning and language learning strategies. In particular, future studies on language learning strategies should consider conceptions of 


\section{IRJE | Indonesian Research Journal in Education | | Vol. 5 | No. 2| December|Year 2021|}

learning as a factor that affect learners' uses of the strategies. In addition, the findings of this study also provide language educators with an additional lens through which learners' language learning strategies phenomena can be better understood. Considering the delimitations of the current study in terms of focus, sample size, and method, further studies that explore the possibilities of the existence of mediating variables between the two constructs as well as ones that examine the contextual influences are recommended. In addition, studies on the relationships between the conceptions of learning and mastery of English language skills are also needed.

\section{Disclosure Statement}

The author certifies that he has no affiliations with or involvement in any organization or entity with any financial or non-financial interest in the subject matter or materials discussed in this paper.

\section{References}

Abbasi, F., Pourshahriar, H., \& Fathabadi, J. (2017). Relationship between conceptions of learning and learning strategies in virtual and real space learners. Information and Communication Technology in Educational Sciences, 7(26), 163-191.

Bahcivan, E., \& Kapucu, S. (2014). Turkish pre-service elementary science teachers' conceptions of learning science and science teaching efficacy beliefs: is there a relationship?. International Journal of Environmental and Science Education, 9(4), 429-442.

Bialystok, E. (1978). A theoretical model of second language learning 1. Language learning, 28(1), 69-83.

Biyikl, C. (2021). The relationship between language learning strategies and academic self-concept. International Journal of Progressive Education, 17(2), 101-123.

Blanch, A., \& Aluja, A. (2013). A regression tree of the aptitudes, personality, and academic performance relationship. Personality and Individual Differences, 54(6), 703-708.

Bond, T. G., \& Fox, C. M. (2013). Applying the rasch model: Fundamental measurement in the buman sciences. New York: Routledge.

Cabaysa, C. C., \& Baetiong, L. R. (2010). Language learning strategies of students at different levels of speaking proficiency. Education Quarterly, 68(1), 16-35

Chaleta, E., Gracio, L., \& Ramalho, G. (2012). Quality of learning in higher education: Students' conceptions of learning as a critical aspect. CIEP - Publicações - Artigos em Revistas Internacionais Com Arbitragem Cientifica, 1-10.

Chaleta, M. E. (2018). Conceptions of learning in higher education students: Reanalysis of the COLI (Conceptions of Learning Inventory). Ensaio: Avaliação e Políticas Públicas em Educação, 26(100), 684-705.

Chan, K. W. (2007). Hong Kong teacher education students: Epistemological beliefs and their relations with conceptions of learning and learning. The Asia Pacific-Education Researcher, 16(2), 199-214.

Chan, K. W. (2011). Preservice teacher education students' epistemological beliefs and conceptions about learning. Instructional Science, 39(1), 87-108. 


\section{IRJE | Indonesian Research Journal in Education | | Vol. 5 | No. 2| December|Year 2021|}

Chand, Z. A. (2014). Language learning strategy use and its impact on proficiency in academic writing of tertiary students. Procedia-Social and Behavioral Sciences, 118, 511-521.

Chiu, Y. C., Liang, J. C., Hsu, H. Y., Chu, T. S., Lin, K. H., Chen, Y. Y., \& Tsai, C. C. (2019). To examine the associations between medical students' conceptions of learning, strategies to learning, and learning outcome in a medical humanities course. BMC medical education, 19(1), 1-14.

Coskun, A. (2010). The Effect of Metacognitive Strategy Training on the Listening Performance of Beginner Students. Online Submission, 4(1), 35-50.

Donche, V., De Maeyer, S., Coertjens, L., Van Daal, T., \& Van Petegem, P. (2013). Differential use of learning strategies in first-year higher education: The impact of personality, academic motivation, and teaching strategies. British Journal of Educational Psychology, 83(2), 238-251.

Fillmore, L. W. (1979). Individual differences in second language acquisition. In Individual differences in language ability and language behavior. New York: Academic Press.

Gan, Z., Liu, F., \& Yang, C. C. R. (2017). Assessment for learning in the chinese context: prospective EFL teachers' perceptions and their relations to learning approach. Journal of Language Teaching and Research, 8(6), 1126-1134.

Gerami, M. H., \& Baighlou, S. M. G. (2011). Language learning strategies used by successful and unsuccessful Iranian EFL students. Procedia-Social and Behavioral Sciences, 29, 1567-1576.

Ghafournia, N. (2014). Language learning strategy use and reading achievement. English Language Teaching, 7(4), 64-73.

Goh, C. C., \& Vandergrift, L. (2021). Teaching and learning second language listening: Metacognition in action. New York: Routledge.

Heidarzadeh, A., Tirgari, B., Azizzadeh Forouzi, M., Shafiean, H., Vadiati, B., \& Saeid, E. (2020). Learning conceptions and study habits: Comparative insight of talented and other students of Kerman university of medical sciences. Educational Development of Judishapur, 11(1), 12-22.

Hemati Alamdarloo, G., \& Moradi, S. (2013). The relationship between students' conceptions of learning and their academic achievement. Psychology, 4(1), 44-49.

Hsiao, T. Y., \& Oxford, R. L. (2002). Comparing theories of language learning strategies: A confirmatory factor analysis. The modern language journal, 86(3), 368-383.

Hulreski, M., Syatriana, E., \& Ardiana, A. (2020). An investigation of deep and surface learning approach towards English vocabulary acquisition of EFL students. Middle Eastern Journal of Research in Education and Social Sciences, 1(1), 15-26.

Irgatoglu, A. (2021). Analysis of language learning strategies and stereotypical thoughts of preparatory school students. Journal of Language and Linguistic Studies, 17(1),1-16.

Jacobs, J. C., Wilschut, J., van der Vleuten, C., Scheele, F., Croiset, G., \& Kusurkar, R. A. (2020). An international study on teachers' conceptions of learning and teaching and corresponding teacher profiles. Medical Teacher, 42(9), 1000-1004.

Kamil, D., Suhaimi, S., Hartono, R., \& Vintoni, A. (2017). TEFL Students' Language Learning Strategies: The Case of One State Islamic Institute in Indonesia. Ta'dib: Jurnal Pendidikan Islam, 22(2), 70-76. 


\section{IRJE | Indonesian Research Journal in Education | | Vol. 5 | No. 2| December|Year 2021|}

Lestari, M., \& Wahyudin, A. Y. (2020). Language learning strategies of undergraduate EFL students. Journal of English Language Teaching and Learning, 1(1), 25-30.

Li, M., Zheng, C., Liang, J. C., Zhang, Y., \& Tsai, C. C. (2018). Conceptions, self-regulation, and strategies of learning science among Chinese high school students. International Journal of Science and Mathematics Education, 16(1), 69-87.

Linacre, J. M. (2006). Data variance explained by rasch measures. Rasch Measurement Transactions, 20(1), 1045.

Lonka, K., Ketonen, E., \& Vermunt, J. D. (2021). University students' epistemic profiles, conceptions of learning, and academic performance. Higher Education, 81(4), 775-793.

Magno, C. (2010). Korean students' language learning strategies and years of studying English as predictors of proficiency in English. Teaching English to Speakers of Languages Journal, 2, 39-61.

Martín, E., Pozo, J. I., Mateos, M., Martín, A., \& Echeverría, M. D. P. P. (2014). Infant, primary and secondary teachers' conceptions of learning and teaching and their relation to educational variables. Revista Latinoamericana de Psicología, 46(3), 211-221.

Marton, F., Dall'Alba, G. A., \& Lai, K. T. (1993). The paradox of the Chinese learner. Paper 93.1 ERADU, RMIT.

Montaño-González, J., \& Cancino, M. (2020). Exploring the relationship between language learning strategies and self-efficacy of Chilean university efl students. Mextesol Journal, 44(2), 1-16.

Mulyani, E. R., Suherdi, D., \& Sundayana, W. (2020). Indonesia Islamic senior high school students' English learning conceptions and strategies. Indonesian Journal of Applied Linguistics, 9(3), 572-579.

Nasab, M. S. B., \& Motlagh, S. F. P. (2015). A complete review for metacognitive, cognitive, and social/affective strategies as essential components of learning strategies and their relationships with efl learners' reading comprehension promotion. Advances in Language and Literary Studies, 6(3), 166-184.

Nazurty, R., Priyanto, N., Anggia Pratiwi, S., \& Mukminin, A. (2019). Learning strategies in reading: the case of Indonesian language education student teachers. Universal Journal of Educational Research, 7(11), 2536-2543.

Negovan, V., Sterian, M., \& Colesniuc, G. M. (2015). Conceptions of learning and intrinsic motivation in different learning environments. Procedia-Social and Behavioral Sciences, 187, 642-646.

Nyikos, M., \& Oxford, R. (1993). A factor analytic study of language-learning strategy use: Interpretations from information-processing theory and social psychology. The Modern Language Journal, 77(1), 11-22.

Obralic, N., \& Mulalic, A. (2017). Correlation between personality traits and language learning strategies among IUS students. Journal of Applied Linguistics and Language Research, 4(5), 76-84.

Oxford, R. L. (1990). Language learning strategies: What every teacher should know. New York, NY: Newbury House /Harper \& Row.

Oxford, R. L., \& Burry-Stock, J. A. (1995). Assessing the use of language learning strategies worldwide with the ESL/EFL version of the strategy inventory for language learning (SILL). System, 23(1), 1-23. 


\section{IRJE | Indonesian Research Journal in Education | | Vol. 5 | No. 2| December|Year 2021|}

Peterson, E. R., Brown, G. T., \& Irving, S. E. (2010). Secondary school students' conceptions of learning and their relationship to achievement. Learning and individual differences, 20(3), 167-176.

Pinto, G., Bigozzi, L., Vettori, G., \& Vezzani, C. (2018). The relationship between conceptions of learning and academic outcomes in middle school students according to gender differences. Learning, culture and social interaction, 16, 45-54.

Pitenoee, M. R., Modaberi, A., \& Ardestani, E. M. (2017). The effect of cognitive and metacognitive writing strategies on content of the Iranian intermediate EFL learners' writing. Journal of Language Teaching and Research, 8(3), 594.

Purdie, N., \& Hattie, J. (2002). Assessing students' conceptions of learning. Australian Journal of Educational and Developmental Psychology, 2, 17-32.

Purdie, N., Hattie, J., \& Douglas, G. (1996). Student conceptions of learning and their use of self-regulated learning strategies: A cross-cultural comparison. Journal of educational psychology, 88(1), 87-100.

Puspita, D. (2016). The correlation between language learning strategies and reading comprehension achievements of the eleventh grade students of SMA N 5 Palembang. Edukasi: Jurnal Pendidikan dan Pengajaran, 3(2), 118-131.

Ranjan, R., \& Philominraj, A. (2020). Language learning strategies, motivation and gender in foreign language context. Universal Journal of Educational Research, 8(2), 591-604

Rianto, A. (2020). A study of language learning strategy use among indonesian efl university students. Register Journal, 13(2), 231-256.

Rubin, J. (1975). What the" good language learner" can teach us. TESOL quarterly, 41-51.

Rubin, J. (1981). Study of cognitive processes in second language learning1. Applied linguistics, 2(2), 117-131.

Sabria, O. (2016). Language learning strategies use in teaching the writing skill for EFL Algerian learners. Arab World English Journal (AWEJ), 7(3), 479-486.

Sadi, Ö. (2017). Relational analysis of high school students' cognitive self-regulated learning strategies and conceptions of learning biology. Eurasia Journal of Mathematics, Science and Technology Education, 13(6), 1701-1722.

Sáljö, R. (1979). Learning in the learners perspective I. Some commonsense conceptions (Report 76). University of Gothenburg, Institute of Education.

Santosa, M. H. (2017). Learning approaches of Indonesian EFL Gen Z students in a Flipped Learning context. Journal on English as a Foreign Language, 7(2), 183-208.

Septikawati, W., Kristina, D., \& Nurkamto, J. (2019). An investigation of language learning strategies used by good language learners in speaking skill. Presented at the UNNES International Conference On ELTLT.

Shen, K. M., Li, T. L., \& Lee, M. H. (2018). Learning biology as 'Increase ones' knowledge and understanding': studying Taiwanese high school students' learning strategies in relation to their epistemic views and conceptions of learning in biology. International Journal of Science Education, 40(17), 2137-2157.

Smith, M. S. (1991). Speaking to many minds: On the relevance of different types of language information for the L2 learner. Interlanguage studies bulletin (Utrecht), 7(2), 118-132. 


\section{IRJE | Indonesian Research Journal in Education | | Vol. 5 | No. 2| December|Year 2021|}

Taheri, H., Sadighi, F., Bagheri, M. S., \& Bavali, M. (2020). Investigating the relationship between Iranian EFL learners' use of language learning strategies and foreign language skills achievement. Cogent Arts \& Humanities, 7(1), DOI: 10.1080/23311983.2019.1710944

Tanjung, F. Z. (2018). Language learning strategies in English as a foreign language classroom in Indonesian higher education context. LLT Journal: A Journal on Language and Language Teaching, 21, 50-68.

Teo, T., Zhou, M., \& Noyes, J. (2016). Teachers and technology: Development of an extended theory of planned behavior. Educational Technology Research and Development, 64(6), 1033-1052.

Tragant, E., \& Victori, M. (2012). Language learning strategies, course grades, and age in EFL secondary school learners. Language Awareness, 21(3), 293-308.

Vettori, G., Vezzani, C., Bigozzi, L., \& Pinto, G. (2020). Cluster profiles of university students' conceptions of learning according to gender, educational level, and academic disciplines. Learning and Motivation, 70, 101628.

Walker, S., Brownlee, J., Whiteford, C., Exley, B., \& Woods, A. (2012). A longitudinal study of change in preservice teachers' personal epistemologies. Australian Journal of Teacher Education, 37(5), 24-35.

Watkins, D., \& Regmi, M. (1992). How universal are student conceptions of learning? A Nepalese investigation. Psychologia: An International Journal of Psychology in the Orient, 35(2), 101-110.

Watkins, D., Regmi, M., \& Astilla, E. (1991). The-Asianas-a-rote-learner stereotype: Myth or reality. Educational Psychology, 17, 89-100.

\section{Biographical Notes}

DAIRABI KAMIL is an Associate Professor in Teaching English as a Foreingn Language (TEFL) at the Faculty of Education and Teacher Training, State Islamic Institute of Kerinci, Jambi, Indonesia. He holds a $\mathrm{PhD}$ from International Islamic University Malaysia (IIUM) in Curriculum and Instruction, an M.Ed in TESOL-International from Monash University, Australia, and BA in English Education from Universitas Jambi. He received a Jambi Province Government scholarship to pursue his $\mathrm{PhD}$ and was a recipent of Australian Development Scholarship (ADS) for his master study. In 2013-2014, he received a sabbatical research grant from the Government of the Republic of Indonesia for his Sabbatical Leave Resarch on Anti-Corruption Education at the Education University of Hong Kong. His research interests include Teaching English as a Foreign Language (TEFL), Language Curriculum and Instruction, Teacher Professional Development and the use of ICT in education. In 2011-2012, He was involved as a researcher in a nationwide program of Analytical and Capacity Development Partnership (ACDP) on Environmental Education in Indonesia, jointly funded by the Government of the Republic of Indonesia and the Asian Development Bank. 